\title{
An Experimental Study on Properties of Concrete using Granite Dust and Flyash as a Partial Replacement of Fine Aggregate \& Cement
}

\author{
Sanjeev Sehgal ${ }^{1}$, Pratiksha Malviya ${ }^{2}$ \\ ${ }^{1}$ M.Tech. Scholar, 2 Professor \\ Department of Civil Engineering, Millennium Institute of Technology \& Science, \\ Bhopal, Madhya Pradesh, India
}

\begin{abstract}
How to cite this paper: Tamil Selvan P | Vinothkumar K | Sugumar $\quad \mathrm{V}$ "Advanced Active Filter (AAF) with Reduced DC Link

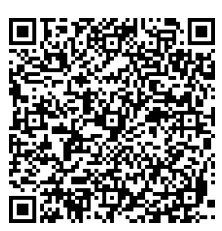

IITSRD22867

Voltage" Published in International Journal of Trend in Scientific Research and Development (ijtsrd), ISSN: 24566470, Volume-3 | Issue-3, April 2019, pp.304-306,

URL:

http://www.ijtsrd.com/papers/ijtsrd22 867.pdf

Copyright (C) 2019

by author(s) and

International

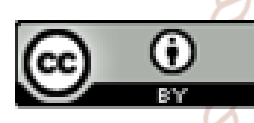

Journal of Trend in Scientific Research and Development Journal. This is an Open Access article distributed under the terms of the Creative Commons Attribution License (CC BY 4.0) (http://creativecommons.org/licenses/ by/4.0)
\end{abstract}

\section{INTRODUCTION}

$>$ Concrete is one of the oldest and most common construction materials in the world, its availability, long durability, and ability to sustain extreme environmental condition.

$>$ Concrete structures are seen everywhere, such as buildings, roads, bridge and dams etc.

The concrete having cement, sand and coarse aggregates mix up in an appropriate percentage in addition to water is called Plain cement concrete.

\section{Objectives}

The objectives of the research are outlined below:

$>$ To check the workability of the concrete by adding fly ash and granite powder.

$>$ The objectives of the present investigations are to investigate the development of Concrete Strength using granite powder as a fine aggregate and also trial mixes by replacing $0,10,20,30$ and 40 percent of the weight of river Sand by Granite powder and $10 \%$ fly ash by cement.

\section{A BSTRAC1} everywhere, reuse of these waste eliminates/reduce the problem. In this 作 cement is replaced $10 \%$ of its weight by fly ash in all strength of the concrete is increased. It is found that the strength increases with the replacement of cement and fine aggregate by fly ash at about $10 \%$ and achieved.

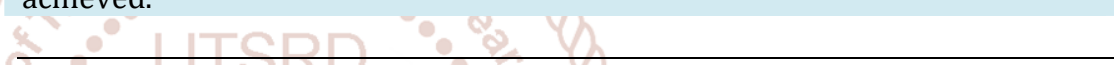

\section{Experimental programmed}

In this stage the experimental work is carried out by using cement, fine aggregate, coarse aggregate, Granite powder and fly ash. The specimens were casted for M30 grade of concrete by replacing the fine aggregate 10\%, 20\%, 30\%, and $40 \%$ by granite powder and $10 \%$ cement is replaced by fly ash. The fresh concrete is tested for workability by slump test while casted specimen is tested for compressive, flexure and split tensile test at the age of 7, 14 and 28 days. The results are shown in tabular as well in graphical form for both the grade of concrete.

\section{Workability Test}

In this work the workability is tested by slump test. When the concrete is freshly mix then it is tested by filling the fresh concrete in the slump cone. The workability is measured by removing the slump cone and measured the subsidence of the concrete this value is called the slump value of the concrete.

The slump value for the M 30 grade of the concrete with using fly ash are shown in the Table. And with using fly ash as cement replacement for $M 30$ grade is shown in the Table 5.2. There graphical representations are shown in the Figure 5.1 . 
International Journal of Trend in Scientific Research and Development (IJTSRD) @ www.ijtsrd.com eISSN: 2456-6470

Table 1 Slump Value of the Different mix M-30 Concrete (with Fly ash)

\begin{tabular}{|c|c|c|c|c|c|c|}
\hline \multirow{2}{*}{ Designation } & \multicolumn{5}{|c|}{ Ingredients } \\
\cline { 2 - 6 } & $\begin{array}{c}\text { Coarse Aggregate } \\
\%\end{array}$ & $\begin{array}{c}\text { Fine Aggregate } \\
\%\end{array}$ & $\begin{array}{c}\text { Granite Powder } \\
\%\end{array}$ & $\begin{array}{c}\text { Cement } \\
\%\end{array}$ & $\begin{array}{c}\text { Fly ash } \\
\%\end{array}$ & Slump Value in (mm) \\
\hline $\mathrm{A}_{1}{ }_{1}-10$ & 100 & 90 & 10 & 90 & 10 & 75 \\
\hline $\mathrm{A}_{1}-20$ & 100 & 80 & 20 & 90 & 10 & 72 \\
\hline $\mathrm{A}_{1}^{\prime}-30$ & 100 & 70 & 30 & 90 & 10 & 63 \\
\hline $\mathrm{A}_{1}^{\prime}{ }_{1}-40$ & 100 & 60 & 40 & 90 & 10 & 56 \\
\hline
\end{tabular}

\section{Slump Value}

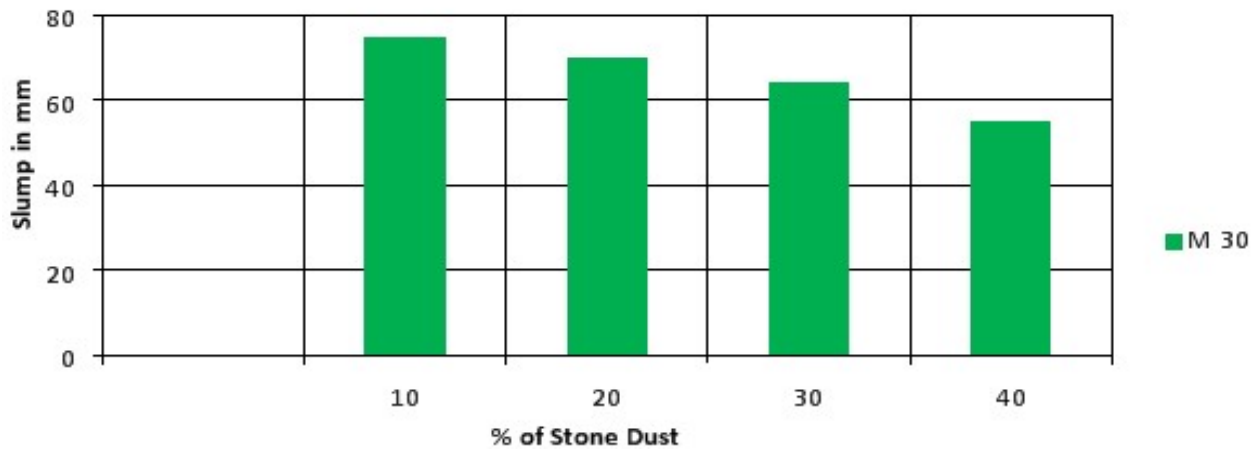

Figure 5.1 Slumps of M-30 with $10 \%$ Flyash

Discussion: By analyzing the slump value, it is understand that the slump value is always decreases by increasing the percentage of the Granite powder and replacing the cement by fly ash. The concrete with fly ash (10\%) has the slump value lower than that of concrete does not contain any fly ash.

\section{COMPRESSIVE STRENGTH TEST}

The result of the compressive strength with partial replacement of Granite powder and without using fly ash for 7, 14 and 28 days are shown for M-30 concrete and their graphical representation in the Figure 5.4 for M-30 Concrete. And by replacing $10 \%$ cement with fly ash along with Granite powder is shown in the Table 5.9 for M-30 concrete and their graphical representation is shown in the Figure 5.5 and Figure 5.6 respectively.

Table 2 Compressive Strength of Different Mix of M-30 Concrete (with Flyash $10 \%$ \& Cement $90 \%$ )

\begin{tabular}{|c|c|c|c|c|c|c|}
\hline Granite Dust & Compressive Strength in N/ $\mathbf{m m}^{2}$ with $\mathbf{1 0} \%$ fly ash & Sand & Cement & \multirow{2}{*}{ Fly ash $\%$} \\
\cline { 1 - 5 }$\%$ & 7 Days & 14 Days & $\mathbf{2 8}$ Days & $\%$ & $\%$ & \\
\hline 0 & 20.02 & 26.62 & 32.52 & 100 & 100 & 0 \\
\hline 10 & 24.74 & 27.42 & 34.36 & 90 & 90 & 10 \\
\hline 20 & 25.96 & 28.9 & 35.8 & 80 & 90 & 10 \\
\hline 30 & 26.32 & 29.21 & 35.26 & 70 & 90 & 10 \\
\hline 40 & 28.8 & 30.6 & 36.96 & 60 & 90 & 10 \\
\hline
\end{tabular}

Discussion: From the above table is seen that the compressive strength with $10 \%$ fly ash and $90 \%$ cement in M 30 grade of concrete at 7, 14 and 28 days increases when the percentage of the Granite powder increase from 10\% to $40 \%$

\section{Compressive Strength in $\mathrm{N} / \mathrm{mm} 2$ with $10 \%$ fly ash}

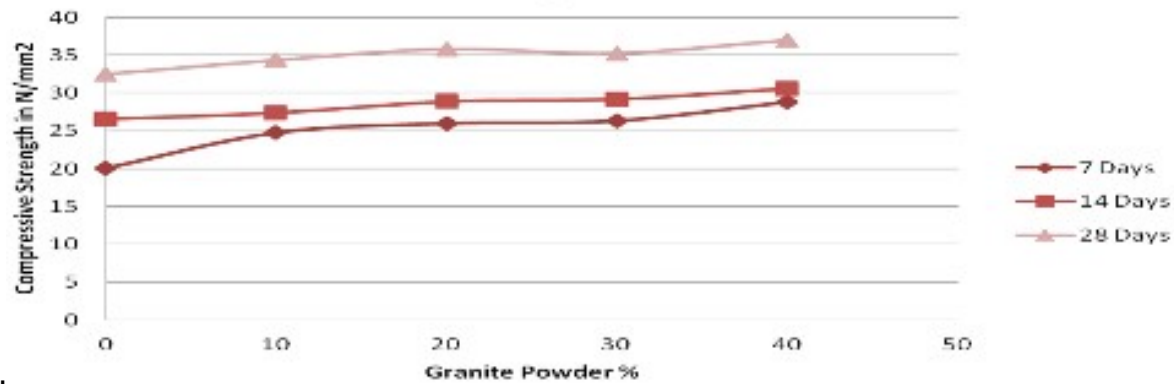

Figure 5.2 Compressive Strength of Different Mix of M-30 Concrete

(With Fly ash $10 \%$ \& Cement $90 \%$ )

\section{FLEXURE STRENGH TEST}

The result of the flexure strength with partial replacement of Granite powderand without using fly ash for 7, 14 and 28 days are shown in for M-30 concrete and their graphical representation in the for M-30 Concrete. And by replacing $10 \%$ cement with fly ash along with Granite powder is shown in the Table. 
International Journal of Trend in Scientific Research and Development (IJTSRD) @ www.ijtsrd.com eISSN: 2456-6470

Table 3 Flexure Strength of Different Mix of M-30 Concrete (with Fly ash 10\% \& Cement 90\%)

\begin{tabular}{|c|c|c|c|c|c|c|}
\hline Granite Dust & \multicolumn{2}{|c|}{ Flexural Strength in N/mm2 } & Sand & Cement & \multirow{2}{*}{ Fly ash \% } \\
\cline { 1 - 5 }$\%$ & 7 Days & 14 Days & 28 Days & $\%$ & $\%$ & \\
\hline 0 & 4.12 & 4.98 & 5.2 & 100 & 100 & 0 \\
\hline 10 & 4.22 & 5.41 & 6.39 & 90 & 90 & 10 \\
\hline 20 & 4.36 & 5.32 & 6.69 & 80 & 90 & 10 \\
\hline 30 & 4.82 & 5.37 & 7.02 & 70 & 90 & 10 \\
\hline 40 & 4.98 & 5.38 & 7.08 & 60 & 90 & 10 \\
\hline
\end{tabular}

Discussion: From the above table is seen that the flexure strength in M 30 grade of concrete with $20 \%$ fly ash and $90 \%$ cement at 7, 14 and 28days increases when the percentage of the Granite powder increase from $10 \%$ to $40 \%$.

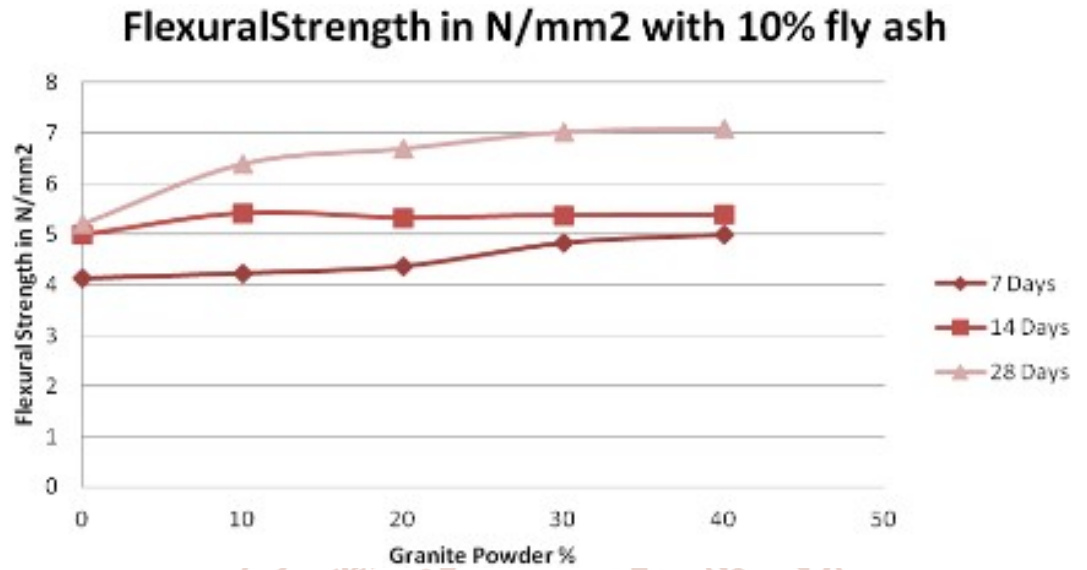

Figure 5.3 Flexure Strength of Different Mix of M-30 Concrete (with Fly ash 10\% \& Cement 90\%)

\subsection{SPLIT TENSILE STRENGH TEST}

The result of the split tensile strength with partial replacement of Granite powder and without using fly ash for 7, 14 and 28 days are shown in the Table 5.15 for M-30 concrete and their graphical representation in the M-30 Concrete. And by replacing $10 \%$ cement with fly ash along with Granite powder is shown in the Table for M-30 concrete and their graphical representation is shown in the Figure.

Table 4 Split Tensile Strength of Different Mix of M-30 Concrete (with Fly ash 10\% \& Cement 90\%)

\begin{tabular}{|c|c|c|c|c|c|c|}
\hline Granite Dust & \multicolumn{2}{|c|}{ Split Tensile Strength in N/mm2 } & Sand & Cement & \multirow{2}{*}{ Fly ash \% } \\
\cline { 1 - 5 }$\%$ & 7 Days & 14 Days & 28 Days & $\%$ & $\%$ & \\
\hline $\mathbf{0}$ & 2.26 & 2.85 & 3.09 & 100 & 100 & 0 \\
\hline $\mathbf{1 0}$ & 3.12 & 3.75 & 4.17 & 90 & 90 & 10 \\
\hline $\mathbf{3 0}$ & 3.15 & 3.58 & 4.25 & 80 & 90 & 10 \\
\hline $\mathbf{4 0}$ & 3.18 & 3.74 & 4.36 & 70 & 90 & 10 \\
\hline
\end{tabular}

Discussion: From the above table is seen that the split tensile strength with $20 \%$ fly ash and $80 \%$ cement in M 30 grade of concrete at 7, 14 and 28 days increases when the percentage of the Granite powder increase from $10 \%$ to $40 \%$.

\section{Split Tensile Strength in N/mm2 with $10 \%$ fly ash}

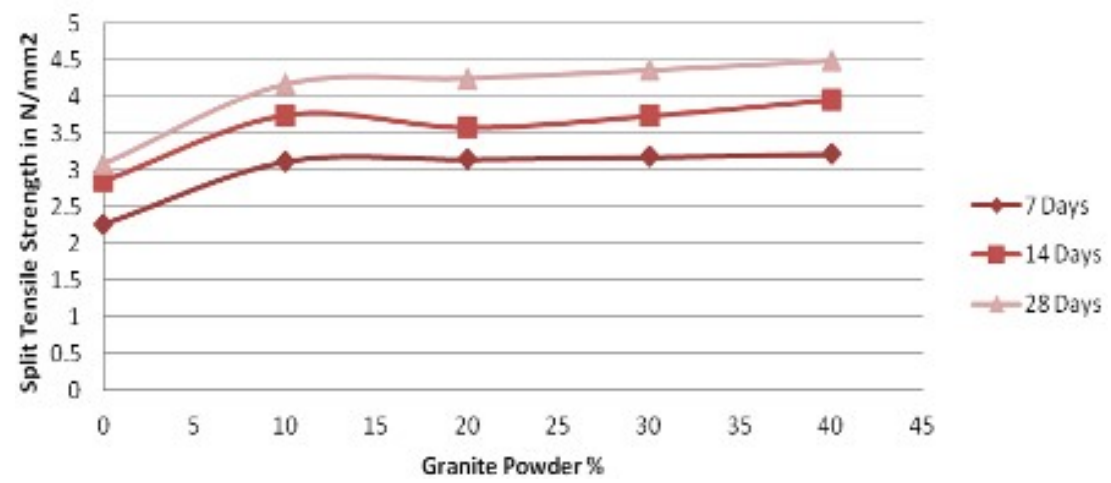

Figure 5.4 Split Tensile Strength of Different Mix of M-30 Concrete (With Fly ash $10 \%$ \& Cement $90 \%$ ) 


\section{Conclusion}

From the above experiments, the study focuses the relative performance of concrete by using the Granite powder as partial replacement of the normal sand and fly ash as partial replacement of cement. From the laboratory study, it can be concluded that the Granite powder is well appropriate for normal sand up to certain limits. And it has better performance as compared to the sand. It is also concluded that the fly ash can be used as cement replacement to certain limits.

\section{REFERENCES}

[1] Abadi, M. H. S. , Delbari, A. , Fakoor, Z. \& Baedi, J. , 2015. Effects of Annealing Temperature on Infrared Spectra of $\mathrm{SiO}_{2}$ Extracted From Rice Husk. J. Ceram. Sci. Tech. , 06(01), pp. 41-46.

[2] Adam, F. , Saraswathy, B. \& Wong, P. L. , 2006. Rice Husk Ash Silica as a Support Material for Ruthenium Based
Heterogenous Catalyst. Journal of Physical Science, Vol . $17(2)$, pp. 1-13.

[3] Ali, F. \& Al-Shawabkeh. , 2015. Evaluation of the Potential Use of Waste Tires as Supplementary Fuel in Jordan Cement Industry. Council for Innovative Research.

[4] Ali, M. B. , Saidur, R. \& Hossain, M. S. , 2011. A Review on Emission Analysis in Cement Industries. Renewable and Sustainable Energy Reviews.

[5] Anderson, J. E. , Wulfhorst, G. \& Lang, W. , 2015. Energy Analysis of the built Environment-A Review and Outlook. Renewable and Sustainable Energy Reviews.

[6] Antiohos S. K. , Papa dakis V. G. \& Tsimas, S. , 2014. Rice husk ash (RHA) effectiveness in cement and concrete as a function of reactive silica and fineness. Cement and Concrete Research.

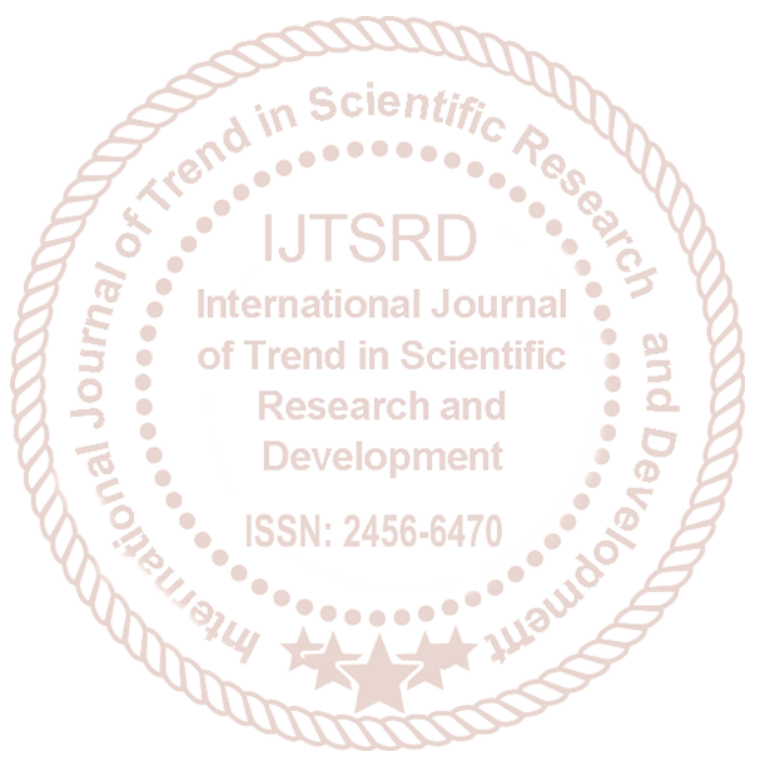

